DOI https://doi.org/10.30525/978-9934-26-173-2-38

\title{
OPTIMIZATION OF THE EDUCATIONAL PROCESS IN STUDENT-DENTISTS UNDER THE CONDITIONS OF THE CORONAVIRUS PANDEMIC
}

\author{
Horokhovskyi V. V. \\ Candidate of Medical Sciences, Associate Professor \\ of Pediatric Dentistry Department \\ Odessa National Medical University \\ Odesa, Ukraine \\ Konovalov M. F. \\ Candidate of Medical Sciences, Associate Professor \\ of Pediatric Dentistry Department \\ Odessa National Medical University \\ Odesa, Ukraine \\ Tarasenko I. Y. \\ Assistant of the Department of Pediatric Dentistry Department \\ Odessa National Medical University \\ Odesa, Ukraine
}

The current COVID-19 pandemic could not but make changes in the work of higher medical institutions in Ukraine. There was a need to search for new forms of education. Remote forms of acquiring knowledge are of great relevance these days $[1,2,3]$.

The purpose of distance learning is to ensure the availability and continuity of education, based on the possibility of advanced training directly at the place of residence or temporary stay of students [1].

In the face of the pandemic, training for most of the country's dental faculties has been shifted online. Despite the fact that medical education cannot be correspondence, it seems that the development of certain skills and abilities is possible in a remote form, which must be implemented in modern realities $[4,5]$. Distance learning offers both a number of benefits and challenges for students and teachers. Among the advantages are a decrease in the spread of the virus among students, the absence of the need to use public transport, convenient planning of working hours, the general availability of education in electronic form, etc $[6,7]$.

Since the introduction of quarantine, the Department of Pediatric Dentistry, ONMedU, has been using Microsoft Teams as the main platform for distance learning. This platform has a number of significant advantages, 
among which it is necessary to note the access of all students to the informational content of the group (lectures, methodological recommenddations of the department, thematic plans and other publications of the group), ease of creating video conferencing, the ability to send a message and a call to any member of the group, allows you to use any modern gadgets for creating a full-fledged workplace. An important advantage of the program is also the ability to show the screen of the device used for the purpose of showing illustrations and presentations.

Despite a number of advantages, in summary terms, the disadvantages of distance learning for future dentists are much more significant. The most important thing is the lack of an opportunity for students to master the whole set of manual skills provided by the educational program, the lack of the possibility of consolidating and improving previously acquired competencies, which is associated with the closure of clinical training bases and the inability of students to access clinical reception. Despite the fact that medical education cannot be correspondence, it seems that the development of certain skills and abilities is possible in a distance form, which must be implemented in modern realities. Due to this, At the Department of Pediatric Dentistry, ONMedU, algorithms for acquiring competencies in the prevention of dental diseases and pediatric therapeutic dentistry were developed and introduced into practice by 2-5 year students in a distance learning format. These algorithms were successfully tested in the academic year 2020 - 2021, the effectiveness of their application was confirmed by the successful passing of the comprehensive final exam OSKE-2.

Summarizing the 2020-21 academic year, the Department of Pediatric Dentistry ONMedU notes an increase in the intellectual and creative potential of subjects of educational activity: stimulating the work of teachers (for effective coordination of the educational process, the teacher must comply with innovations, is interested in constantly increasing the level of teaching his subject) and the process of teaching students (students have the opportunity to more effectively use their time for training). In addition, the use of modern computer technologies has a positive effect on the degree of perception of information by a person and the development of his cognitive functions, contributes to the development of self-organization and selfactivity of the future doctor. The advantages of distance medical education include reducing the cost of training, the solution problems of personnel in the university, the absence of the problem of coordinating schedules. The disadvantages of distance learning include technical difficulties that arise during classes (low quality of the Internet connection, interruptions in the work of computers for some students). 
Thus, along with the widespread use of platforms adapted directly for distance learning (Microsoft teams, Zoom), the use of additional computer applications in the preparation of dental students can become a solution to many problems related to both educational and clinical activities of teachers and students of dental faculties of higher education. educational institutions of Ukraine. Consequently, distance learning is a potential resource that provides an opportunity for dental students to independently improve their level of knowledge.

Given that the COVID-19 pandemic continues, it is necessary to constantly methodologically improve the distance learning technologies for future specialists.

Departments of the dental profile need to use more broadcasts of symposia, conferences, clinical analyzes held in medical and educational institutions.

\section{References:}

1. Kreitlow A. Support for global health and pandemic preparedness in medical education in Germany: Students as change agents / Health Planning and Management. 2021.https: //doi.org/10.1002/hpm.3143

2. Tempski P. Medical students' perceptions and motivations during the COVID-19 pandemic / Plos. 2021.https://doi.org/10.1371/ journal.pone. 0248627

3. Itinson K.S., Chirkova V.M. On the issue of the efficiency of using electronic resources in the learning process of foreign students at a medical school. Baltic Humanitarian Journal. 2019. Vol. 8. No. 1 (26). S. 233-236.

4. Zelenko L.S. Application of mobile technologies in distance learning // Innovative information technologies. 2013. No. 2. S. 169-170.

5. Сизова Ж.М., Трегубов В.Н., Малахова Т.Н. Актуальные вопросы подготовки врачей-стоматологов к аккредитации специалистов // Стоматология. 2017. Т. 96, № 2. С. 66-69.

6. Блохин А.Л. Мотивация студента, как одна из составляющих формирования человеческого капитала // Проблемы современного педагогического образования. 2016. Т. 53, № 3. С. 37-43.

7. Богданов Ю.В. Мотивация студента к обучению: Теория и практика // Terra Economicus. 2013. T. 11, № 4-3. С. 253-257. 